\title{
MORPHOMETRIC STUDY OF PITUITARY GLAND WITH CORRELATION OF AGE AND GENDER USING MAGNETIC RESONANCE IMAGING
}

\author{
Sunima Maskey ${ }^{1 *}$, Dil Islam Mansur ${ }^{2}$, Subindra Karki ${ }^{3}$, Pragya Shrestha $^{4}$, Sheprala Shrestha ${ }^{1}$, Mukta Singh Bhandari $^{5}$
}

\section{Affiliation}

1. Lecturer, Department of Anatomy, Kathmandu University School of Medical Sciences, Nepal

2. Associate Professor, Department of Anatomy, Kathmandu University School of Medical Sciences, Nepal

3. Associate Professor, Department of Radiology, Kathmandu University School of Medical Sciences, Nepal

4. Assistant Professor, Department of Anatomy, Kathmandu University School of Medical Sciences, Nepal

5. Assistant Professor, Department of Community Medicine, Kathmandu University School of Medical Sciences, Nepal

\section{ARTICLE INFO}

Received : 18 March, 2021

Accepted : 12 May, 2021

Published : 04 November, 2021

(C) Authors retain copyright and grant the journal right of first publication with the work simultaneously licensed under Creative Commons Attribution License CC - BY 4.0 that allows others to share the work with an acknowledgment of the work's authorship and initial publication in this journal.

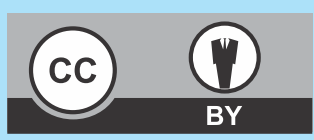

\section{ORA 254}

DOI: https://doi.org/10.3126/bjhs.v6i2.40322

\section{* Corresponding Author \\ Dr Sunima Maskey Lecturer \\ Department of Anatomy}

Kathmandu University School of Medical Science, Nepal Email: sunima.maskey@gmail.com ORCID: https://orcid.org/0000-0002-8193-0415

\section{Citation}

Sunima Maskey, Dil Islam Mansur, Subindra Karki, Pragya Shrestha, Sheprala Shrestha, Mukta Singh Bhandari.Morphometric study of pituitary gland with correlation of age and gender using Magnetic Resonance Imaging. BJHS 2021;6(2)15. 1476-1480.

\section{ABSTRACT}

\section{Introduction}

The pituitary gland is the master gland of the body. It's size varies with age and gender. MRI is the safest and effective diagnostic tool for pituitary gland examination.

\section{Objectives}

This study was aim to determine the anteroposterior, height and transverse dimensions of normal pituitary gland in different age groups of both sex with MRI.

\section{Methodology}

It was a descriptive cross-sectional study. It consisted of 567 images of individuals (242 males and 325 females) of various age from 20 to 70 years from the Department of Radiodiagnosis, Dhulikhel Hospital.

\section{Result}

The mean anteroposterior, height and transverse dimension of pituitary gland is $9.74 \pm 1.18 \mathrm{~mm}, 5.95 \pm 1.11 \mathrm{~mm}$ and $11.65 \pm 2.15 \mathrm{~mm}$ respectively in which females have higher value. Independent sample t test showed highly significant differences $(p<0.05)$ between the mean anteroposterior dimension in males and females. The present study showed the mean value of anteroposterior dimension is maximum at age group 50-59. The mean value of height, transverse dimension and volume of males and females is maximum at 20-29 age group and minimum at 70-79 age group. One way ANOVA shows that there is significant difference between in height, transverse dimension and volume at different age group $(p<0.05)$.

\section{Conclusion}

It was concluded that the height and volume of pituitary gland is maximum at second decade of life then it gradually decreases with age. The mean value of anteroposterior, height and transverse dimension showed greater value of females than males.

\section{KEYWORDS}

Anatomy, Magnetic resonance imaging, Pituitary gland. 


\section{INTRODUCTION}

The pituitary gland is the master gland which controls almost all the activities of other gland in the body. ${ }^{1}$ It is a reddish gray in color, ovoid in shape and measures about 8 $\mathrm{mm}$ in anteroposterior, $12 \mathrm{~mm}$ in transverse dimension and $5.9 \mathrm{~mm}$ height. ${ }^{2,3}$ It is located within the hypophyseal fossa of sphenoid bone and covered by a diaphragm sellae. ${ }^{1,2}$

Magnetic resonance imaging (MRI) generate image using the nuclei of atoms inside the body which is specifically useful for soft tissues visualization. ${ }^{4}$ It is considered safe for studies since it does not use any harmful ionizing radiations and provides high resolution images. ${ }^{5}$ Likewise It is the most accurate and preferable diagnostic technique for pituitary gland. 6,7

Studies have claimed the variation size of pituitary gland associated with age, gender and pathological condition..$^{8,9}$ As the size varies with age, it is very important to find the morphological dimension and correlation with age and gender. There are several disorders of pituitary gland such as pituitary adenomas, inflammation, hypertrophyetc which may affect size and shape of gland. ${ }^{6,10}$ Due to variations in size and shape of pituitary with age, pituitary volume is taken as the best predictor of pituitary gland size. ${ }^{11}$

Morphometric analysis of pituitary gland has been studied by many researchers worldwide because of its importance. Knowledge of accurate anatomical measurements of it is important for clinician for better prognosis of the diseases. The data is not sufficiently available for Nepalese population. Thus, the present study was aimed to evaluate pituitary morphometry by using MRI images.

\section{METHODOLOGY}

A descriptive cross-sectional study was conducted in the Department of Anatomy and data was collected from the Department of Radio- diagnosis, Dhulikhel Hospital/ Kathmandu University Hospital, Dhulikhel, Nepal by using images of MRI scan. MRI was performed with a 1.5 Tesla Ingenia Philips machine. The ethical clearance was obtained from IRC-KUSMS (Ref. no. 50/19).The convenient sampling technique was used for data collection. Total number of 567 images of individuals ( 242 males and 325 females) of various age from 20 to 70 years were taken from June 2019 to December 2020. The obtained data were studied under different age groups and each ten years were grouped as an age group. Hence, the present study consisted of 20-29, 30$39,40-49,50-59,60-69$ and $70-79$ years age groups. ${ }^{3}$ The pituitary gland dimensions were measured by lines drawn on the images using options provided in the Digital Imaging and Communications in Medicine software and the values were directly recorded from the monitor screen in millimeter $(\mathrm{mm})$. The images of individuals with routine MRI images were studied showing normal anatomy. Pathological condition with history of pituitary gland or hormone disorders, infarction, raised intra cranial pressure and unclear abnormal features of gland were excluded.

$3 \mathrm{D}$ volumetric sagittal scan was performed and reconstruction done of axial coronal and sagittal. The mid sagittal image measured anteroposterior dimension and height (craniocaudal) [Figure-1]. The coronal image measured transverse dimension [Figure-2]. Pituitary gland volume was estimated by using formula: $\mathrm{V}=$ anteroposterior dimension $\mathrm{x}$ height $\mathrm{x}$ transverse dimension $\times 0.52 .^{8}$

Data was collected and entered in Microsoft excel and analyzed using the Statistical Package for the Social Sciences version $\mathbf{1 6 . 0}$ for descriptive statistical analysis. P-value was calculated to find the level of significance and $P$ value $<0.05$ was considered as significant.

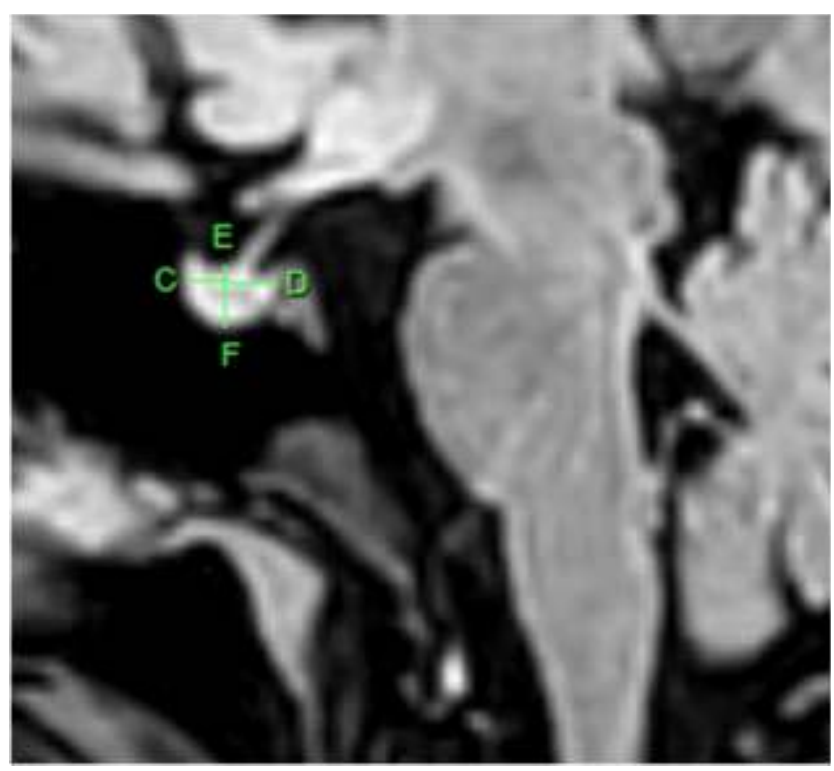

Figure 1: C-D shows measurement of anteroposterior dimension, E-F shows measurement of height.

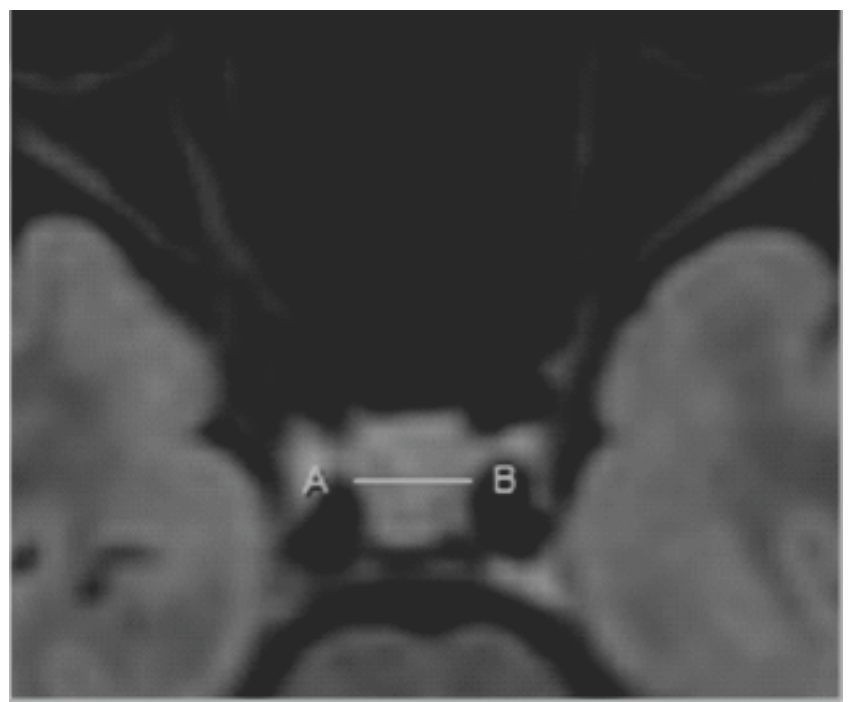

Figure 2: A-B shows measurement of transverse dimension.

\section{RESULTS}

The mean anteroposterior, height and transverse dimension of pituitary gland in which all values of females were found to be more than males is described in Table 1. Independent sample t test showed highly significant differences $(p<0.05)$ between the mean anteroposterior dimension in males and females. 
Table 1: Anteroposterior dimension, height, transverse dimension and volume of pituitary gland.

\begin{tabular}{|l|l|l|l|l|}
\hline & \multicolumn{1}{|c|}{$\begin{array}{c}\text { Anteroposterior } \\
\text { dimension }(\mathrm{mm})\end{array}$} & Height $(\mathrm{mm})$ & $\begin{array}{c}\text { Transverse } \\
\text { Dimension }(\mathbf{m m})\end{array}$ & Volume $\left(\mathrm{mm}^{3}\right)$ \\
\hline Total $(567)$ & $9.74 \pm 1.18$ & $5.95 \pm 1.11$ & $11.65 \pm 2.15$ & $352.51 \pm 107.74$ \\
\hline Males(242) & $9.62 \pm 1.08$ & $5.87 \pm 1.10$ & $11.56 \pm 2.14$ & $341.17 \pm 103.29$ \\
\hline Females(325) & $9.83 \pm 1.25$ & $6.01 \pm 1.12$ & $11.72 \pm 2.16$ & $360.96 \pm 110.33$ \\
\hline p-value & 0.03 & 0.13 & 0.38 & 0.03 \\
\hline
\end{tabular}

Furthermore, the mean value of anteroposterior, height and transverse dimension of pituitary gland in different age group is shown in Table 2. The present study showed the mean value of anteroposterior dimension is maximum at age group 50-59 yrs. It was found that the height, transverse dimension and volume is highest at 20-29yrs age group. One way ANOVA shows that there is significant difference between in height, transverse dimension and volume at different age group ( $p<0.05)$.

The mean value of anteroposterior, height, transverse dimension and volume of pituitary gland in different age group and in both sex is described in Table 3 .

Anteroposterior dimension: The mean value of group i.e. $5.31 \pm 1.17 \mathrm{~mm}$ and $5.42 \pm 1.22 \mathrm{~mm}$ respectively (Table 3). This study coated that the mean value of height of females is greater than males in all age group except at 6069 yrs age group.

Transverse dimension: The mean value of transverse dimension of males and females is maximum at 20-29 yrs age group $12.18 \pm 1.95 \mathrm{~mm}$ and $12.07 \pm 1.89 \mathrm{~mm}$ respectively and minimum at $70-79$ yrs age group $9.24 \pm 2.95 \mathrm{~mm}$ and $10.87 \pm 1.75 \mathrm{~mm}$ respectively (Table 3 ). The present study showed that the mean value of transverse dimension of males at 20- 29 yrs and 50- 59 yrs age group is greater than females.

Volume: The mean value of volume of males and females is maximum at 20-29 yrs age group (377.5 $\pm 94.94 \mathrm{~mm}^{3}$ and

Table 2: Pituitary gland in different age groups.
\begin{tabular}{|l|l|l|l|l|}
\hline \multicolumn{1}{|c|}{$\begin{array}{c}\text { Age Group } \\
(\mathrm{yrs})\end{array}$} & $\begin{array}{c}\text { Anteroposterior } \\
\text { dimension } \\
(\mathrm{mm})\end{array}$ & $\begin{array}{c}\text { Height } \\
(\mathrm{mm})\end{array}$ & $\begin{array}{c}\text { Transverse } \\
\text { dimension } \\
(\mathrm{mm})\end{array}$ & Volume $\left(\mathrm{mm}^{3}\right)$ \\
\hline $20-29$ & $9.82 \pm 1.21$ & $6.30 \pm 1.07$ & $12.11 \pm 1.91$ & $751.47 \pm 205.75$ \\
\hline $30-39$ & $9.71 \pm 1.13$ & $6.00 \pm 1.17$ & $11.93 \pm 2.07$ & $696.72 \pm 215.85$ \\
\hline $40-49$ & $9.66 \pm 1.28$ & $5.77 \pm 0.98$ & $11.80 \pm 2.16$ & $659.50 \pm 188.45$ \\
\hline $50-59$ & $9.90 \pm 1.14$ & $5.66 \pm 1.00$ & $10.78 \pm 2.10$ & $602.81 \pm 165.89$ \\
\hline $60-69$ & $9.47 \pm 0.97$ & $5.61 \pm 1.21$ & $11.21 \pm 2.28$ & $592.92 \pm 185.43$ \\
\hline $70-79$ & $9.51 \pm 1.18$ & $5.35 \pm 1.16$ & $9.84 \pm 2.64$ & $504.30 \pm 200.27$ \\
\hline $\begin{array}{l}\text { P-value } \\
\text { (one way ANOVA) }\end{array}$ & 0.25 & 0.00 & 0.00 & 0.00 \\
\hline
\end{tabular}

anteroposterior dimension of males is maximum $(10.05 \pm 0.97 \mathrm{~mm})$ at 50 -59yrs age group and minimum $(9.32 \pm 1.15 \mathrm{~mm})$ at $70-79$ yrs age group. Similarly, the mean value of anteroposterior dimension of females is maximum $(10.01 \pm 1.31 \mathrm{~mm})$ at $20-29 \mathrm{yrs}$ age group and minimum $(9.40 \pm 1.05 \mathrm{~mm})$ at $60-69 \mathrm{yrs}$ age group. The mean values of females is larger in all group except 50-59 yrs and 60-69yrs age group (Table 3).

Height: The mean value of height of males and females is highest at 20-29 yrs age group i.e. $6.19 \pm 0.99 \mathrm{~mm}$ and $6.38 \pm 1.13 \mathrm{~mm}$ respectively and lowest at 70-79 yrs age
$401.42 \pm 115.16 \mathrm{~mm}^{3}$ respectively) and minimum at $70-79$ yrs age group $\left(236.95 \pm 96.08 \mathrm{~mm}^{3}\right.$ and $305.58 \pm 110.18$ $\mathrm{mm}^{3}$ respectively). The differences between the mean volume in males and females at all groups were found to be insignificant except at 20-29 yrs age group where it is highly significant $(p<0.05)$ (Table 3$)$. The conducted study showed that the mean value of volume at $50-59$ yrs age group had higher value for males than females. The mean volume of gland shows significant association with puberty age with maximum value at $20-29$ yrs age group which is gradually decreasing with the age. 
Table 3: Pituitary gland in different age group in both sex.

\begin{tabular}{|c|c|c|c|c|c|c|c|c|c|}
\hline $\begin{array}{c}\text { Age Group } \\
\text { (yrs) }\end{array}$ & Sex & $\begin{array}{l}\text { Anteroposterior } \\
\text { dimension }(\mathrm{mm})\end{array}$ & $\overline{p \text {-value }}$ & $\begin{array}{l}\text { Height } \\
(\mathrm{mm})\end{array}$ & p-value & $\begin{array}{c}\text { Transverse } \\
\text { Dimension } \\
(\mathrm{mm})\end{array}$ & p-value & Volume $\left(\mathrm{mm}^{3}\right)$ & p-value \\
\hline \multirow[t]{2}{*}{$20-29$} & Males & $9.58 \pm 1.04$ & \multirow[t]{2}{*}{0.08} & $6.19 \pm 0.99$ & \multirow[t]{2}{*}{0.14} & $12.18 \pm 1.95$ & \multirow[t]{2}{*}{0.71} & $377.5 \pm 94.94$ & \multirow[t]{2}{*}{0.02} \\
\hline & Females & $10.01 \pm 1.31$ & & $6.38 \pm 1.13$ & & $12.07 \pm 1.89$ & & $401.42 \pm 115.16$ & \\
\hline \multirow[t]{2}{*}{$30-39$} & Males & $9.51 \pm 1.15$ & \multirow[t]{2}{*}{0.15} & $5.90 \pm 1.28$ & \multirow[t]{2}{*}{0.49} & $11.84 \pm 2.08$ & \multirow[t]{2}{*}{0.72} & $344.36 \pm 113.32$ & \multirow[t]{2}{*}{0.19} \\
\hline & Females & $9.84 \pm 1.11$ & & $6.06 \pm 1.10$ & & $11.99 \pm 2.08$ & & $373.86 \pm 110.91$ & \\
\hline \multirow[t]{2}{*}{$40-49$} & Males & $9.49 \pm 1.23$ & \multirow[t]{2}{*}{0.78} & $5.66 \pm 1.02$ & \multirow[t]{2}{*}{0.38} & $11.60 \pm 1.45$ & \multirow[t]{2}{*}{0.52} & $328.09 \pm 89.91$ & \multirow[t]{2}{*}{0.41} \\
\hline & Females & $9.78 \pm 1.33$ & & $5.83 \pm 0.93$ & & $11.90 \pm 2.55$ & & $351.72 \pm 102.03$ & \\
\hline \multirow[t]{2}{*}{$50-59$} & Males & $10.05 \pm 0.97$ & \multirow[t]{2}{*}{0.38} & $5.59 \pm 1.05$ & \multirow[t]{2}{*}{0.42} & $10.99 \pm 1.87$ & \multirow[t]{2}{*}{0.17} & $322.11 \pm 90.69$ & \multirow[t]{2}{*}{0.36} \\
\hline & Females & $9.89 \pm 1.25$ & & $5.72 \pm 0.95$ & & $10.69 \pm 2.29$ & & $310.33 \pm 82.04$ & \\
\hline \multirow[t]{2}{*}{$60-69$} & Males & $9.57 \pm 0.88$ & \multirow[t]{2}{*}{0.53} & $5.73 \pm 1.09$ & \multirow[t]{2}{*}{0.54} & $10.85 \pm 2.77$ & \multirow[t]{2}{*}{0.33} & $310.03 \pm 111.85$ & \multirow[t]{2}{*}{0.91} \\
\hline & Females & $9.40 \pm 1.05$ & & $5.52 \pm 1.31$ & & $11.48 \pm 1.85$ & & $307.07 \pm 85.36$ & \\
\hline \multirow[t]{2}{*}{$70-79$} & Males & $9.32 \pm 1.15$ & \multirow[t]{2}{*}{0.45} & $5.31 \pm 1.17$ & \multirow[t]{2}{*}{0.85} & $9.24 \pm 2.95$ & \multirow[t]{2}{*}{0.20} & $236.95 \pm 96.08$ & \multirow[t]{2}{*}{0.19} \\
\hline & Females & $9.79 \pm 1.27$ & & $5.42 \pm 1.22$ & & $10.87 \pm 1.75$ & & $305.58 \pm 110.18$ & \\
\hline
\end{tabular}

\section{DISCUSSION}

Pituitary gland is very important neuro endocrine organ which secrete hormones that is essential for life. ${ }^{2} \mathrm{MRI}$ is most preferable diagnostic technique for the examination of soft tissues. ${ }^{6,7}$ It is therefore important to get normal pituitary gland value of MRI images. Pituitary gland variations are noted among individuals from different part of the world. ${ }^{8,9}$ Change in the shape and size often affected by age and gender. The variations in size also reflects hormonal function imbalance. ${ }^{10}$

In our study the overall mean height was $5.95 \pm 1.11 \mathrm{~mm}$ which is lesser than the study done by Yadav et al., Lamichhane et al. and Kumar. ${ }^{3,8,12}$ In contrast, the finding of Suzuki et al. has lower mean value than our study. ${ }^{9}$ Fewer study done by Mohammad et al., Kato et al., Shayma et al. and Grams et al. showed the mean value of height almost comparable with our study. ${ }^{13-16}$

Many studies done in different places showed there is maximum increase of height of pituitary gland in their second decade of life which is similar with our study. ${ }^{14,15,17}$ This suggest the change of hormonal levels which cause changes in morphology of the gland.

The decline in the height of gland with age also shows the hormonal changes with aging and physiological atrophy. In our study minimum mean height $(5.35 \pm 1.16 \mathrm{~mm})$ was found in the age group of 70-79 yrs which was supported by the study done by Lamichhane et al. and Sinclair et al. ${ }^{3,17}$

Studies reveal that the gland height is significantly greater among the adolescent women than men which is physiological hypertrophy. ${ }^{10}$ Consequently, the mean height of gland in females was greater than that of males in the same age group except in the age group 60-69 yrs. In present study the mean value of height of males and females is maximum at $20-29$ yrs age group $(6.19 \pm 0.99 \mathrm{~mm}$ and $6.38 \pm$ $1.13 \mathrm{~mm}$ respectively and minimum at $70-79 \mathrm{yrs}$ age group (5.31 $\pm 1.17 \mathrm{~mm}$ and $5.42 \pm 1.22 \mathrm{~mm}$ respectively). Study done by Suzuki et al. and Kato et al. reported maximum mean height in females was found at 20-30 yrs age group which supported our study., ${ }^{9,14}$ However the study done by Kumar and Muhammad et al. also reported the greatest mean value at 20-30 yrs age group but the males had higher values. ${ }^{12,18}$

In our study the total mean height for females $(6.01 \pm 1.12$ $\mathrm{mm})$ is greater than males $(5.87 \pm 1.10 \mathrm{~mm})$ which is similar with the study done among Japanese, Scottish, Nigerian population. ${ }^{14,17,19}$

Many studies have reported the value of anteroposterior dimension is greater than our study $(9.74 \pm 1.18 \mathrm{~mm}){ }^{13,14,16}$ Lamichhane et al., Sinclair et al. and Shayma et al. also studied the anteroposterior dimension and their results are remarkably similar with the data produced in this study with a mean value of $9.90 \pm 1.14 \mathrm{~mm}$ maximum at $50-59$ yrs age group. ${ }^{3,15,17}$

The present study observed that the mean values of anteroposterior dimension of males $(9.62 \pm 1.08 \mathrm{~mm})$ and females $(9.83 \pm 1.25 \mathrm{~mm})$ is lower than the study conducted by Kato et al., Sinclair et al. and Ibinaiye et al. . $^{14,17,19}$

The result from this study give a mean value of $11.65 \pm 2.15$ $\mathrm{mm}$ for transverse dimension of gland which is comparatively smaller than the value reported by other studies. ${ }^{3,16,17}$ A study done by Sinclair et al. showed similar result with a maximum mean transverse dimension of pituitary gland of $12.11 \pm 1.91 \mathrm{~mm}$ for 20-29yrs age group. ${ }^{17}$

In this study the total mean transverse dimension for females $(11.72 \pm 2.16 \mathrm{~mm})$ is greater than males $(11.56 \pm 2.14$ $\mathrm{mm}$ ) which agreed the study done by Kato et al., Sinclair et al. and Ibinaiye et al. ${ }^{14,17,19}$

The present study showed that the mean value of volume to be $352.51 \pm 107.74 \mathrm{~mm}^{3}$ similar finding was observed among the Sudanese population. ${ }^{15}$ A study done on Inedial Indian population showed the lower mean value than ours. ${ }^{20}$

Generally, the volume were higher at the early puberty age than in the declining years. The present study revealed the maximum mean value is for the age group 20-29 yrs $\left(751.47 \pm 205.75 \mathrm{~mm}^{3}\right)$ then it gradually decrease with age. Similar the study done among Sudanese, Indian, Nepali, Nigerian and Kashmiri population showed maximum volume at 20-29 yrs age group which supported our study. $3,8,12,15,19$

A study done in India revealed the value of mean volume of 
females $\left(360.96 \pm 110.33 \mathrm{~mm}^{3}\right)$ is greater than that of males $(341.17 \pm 103.29 \mathrm{~mm} 3)$ which is similar to our study. ${ }^{11}$ In contrast, Ibinaiye et al. reported larger values in male. ${ }^{19}$

\section{CONCLUSION}

The present study showed the height and volume of pituitary gland is maximum at second decade of life then it gradually decreases with age. The mean value of anteroposterior, height and transverse dimension showed greater value of females than male. It could also establish normal reference values for MRI of pituitary gland which may be used in diagnosis and treatment of diseases.

\section{RECOMMENDATIONS}

It is highly recommended to conduct similar study including large population to see the sexual dimorphism in Nepalese population.

\section{LIMITATIONS OF THE STUDY}

Study could not include the population from other part of the country so the result obtained from this study could not be generalized to other population.

\section{ACKNOWLEDGEMENTS}

Authors would like to thank staffs of the Department of Radio-diagnosis, Dhulikhel Hospital for their cooperation and help in data collection.

\section{CONFLICT OF INTEREST}

None

\section{FINANCIAL DISCLOSURE}

None

\section{REFERENCES}

1. Kulkarni NV. Pituitary gland. Clinical anatomy, 2nd edition. Jaypeebrothers medical publishers, New Delhi 2012. p. 508-9.

2. Standring S. Diencephalon. Gray's anatomy the anatomical basis of clinical practice, 39th edition. Churchill-Livingstone: Elsevier, London 2005. p. 321-3.

3. Lamichhane TR, Pangeni S, Paudel S, Lamichhane HP. Age and gender related variations of pituitary gland size of healthy Nepalese people using Magnetic Resonance Imaging. Am. J. Biomed. Eng. 2015; 5(4): 130-135. DOI: 10.5923/j.ajbe.20150504.03

4. Chauhan R, Gambhir M. Various techniques used in radiology. Surface and radiological anatomy, 1st edition. Avichal publishing company, New Delhi 2018. p. 117-21.

5. Zrazhevskiy P, Mark S, Xiaohu G. Designing multifunctional quantum dots for bioimaging, detection, and drug delivery. ChemSoc Rev. 2010; 39(11): 4326-54. DOI: 10.1039/b915139g

6. Tsunoda A, Okuda O, Sato K. MR height of the pituitary gland as a function of age and sex: especially physiological hypertrophy in adolescence and in cimacterium. Am J Neuroradiol. 1997; 18:551-4. PMID : 9090422

7. Davis PC, Hoffman C, Spencer T, Tindall GT, Braun IF. MR imaging of pituitary adenoma: CT, clinical, and surgical correlation. Am J Roentgenol.1987 April; 148: 797-802. DOI : 10.2214/ajr.148.4.797

8. Yadav $P$, Singhal S, Chauhan S, Harit S. MRI evaluation of size and shape of normal pituitary gland: age and sex related changes. J. clin. diagn. 2017; 11(12):1-4. DOI: 10.7860/JCDR/2017/31034.10933

9. Suzuki M, Takashima T, Kadoya M, Konishi H, Kameyama T, Yoshikawa J et al. Height of normal pituitary gland on MR imaging: Age and sex differentiation. J Comput Assist Tomogr. 1990; 14(1): 36-9. DOI: 10.1097/00004728-199001000-00006

10. Elster AD, Chen MYM, Williams DW, Key LL. Pituitary gland: MR imaging of physiologic hypertrophy in adolescence. Radiology. 1990; 174: 681-8. DOI : https://doi.org/10.1148/radiology. 174.3.2305049

11. Kumar JU, Kavitha Y. MR volumetry of pituitary gland in Indian adults to establish normal refrencevalues. Int $\mathrm{j}$ anatradiol surg. 2017; 6(1): 36-9. DOI: 10.7860/IJARS/2017/24458:2239
12. Kumar A. Mri evaluation of normal pituitary gland with age and sex related variations in Kashmiri population. Indian J. Sci. Res. 2019; 10(1): 165-70.DOI: 10.32606/IJSR.V10.I1.00025

13. Mohammad S, Hossein AE, Habibeh AP, Mohammad K. Height, shape and anterior-posterior diameter of pituitary gland on magnetic resonance imaging among patients with multiple sclerosis compared to normal individuals. Iran J Neurol. 2017; 16(4):218-20. PMID : 29736228

14. Kato K, Saeki N, Yamaura A. Morphological changes on MR imaging of the normal pituitary gland related to age and sex: main emphasis on pubescent females. J Clin Neurosci. 2002; 9(1): 53-6. DOI: 10.1054/jocn.2001.0973

15. Shayma H, Ayad CE, Rana AE, Awadia G, Alaa I, Moawia G et al. The pituitary gland measurements in Sudanese females using magnetic resonance imaging. Int. J. Biomed. 2020; 10(4): 397-401. DOI : 10.21103/ Article10(4)_OA13

16. Grams AE, Gempt J, Stahl A, forschler A. Femalespituitary size in relation to age and hormonal factors. Neuroendocrinology. 2010; 92: 128-32. DOI: 10.1159/000314196

17. Sinclair J, Kanodia AK, Schembri N, Sudarshan T, Guntur P. MRI measurement of normal pituitary size using volumetric imaging in Scottish patients. Current Trends in Curr Trends Clin Med Imaging. 2017 April; 1(3): 43-7. DOI: 10.19080/CTCMI.2017.01.555563

18. Muhammad FI, Zafar S, Ishrat S, Amir O. Pituitary height on Magnetic Resonance Imaging observation of age and sex related changes. J Pak Med Assoc. 2008; 58(5): 261-4. PMID : 18655404

19. Ibinaiye PO, Olarinoye-Akoreda S, Kajogbola O, Bakari AG. Magnetic resonance imaging determination of normal pituitary gland dimension in Zaria, Northwest Nigerian Population. J Clin Imaging Sci. 2015; 5:29. DOI:10.4103/2156-7514.157853

20. Raghuprasad MS, Manivannan M. Volumetric and morphometric analysis of pineal and pituitary glands of an Indian inedial subject. Ann Neurosci. 2018; 25: 279-88. DOI: 10.1159/000487067 